\title{
Difficulties in Translating TV Programs in English into Vietnamese: A Study at Lam Dong Radio - Television Station
}

\author{
Ph.D, Nguyen Thi Kieu Thu ${ }^{1}$, Nguyen Le Uyen Minh ${ }^{2 *}$ \\ ${ }^{1}$ Ho Chi Minh City University of Technology, Vietnam \\ ${ }^{2}$ Lam Dong Radio and Television Station, Vietnam
}

\author{
*Corresponding Author: Nguyen Le Uyen Minh, Lam Dong Radio and Television Station, Vietnam
}

\begin{abstract}
This study examined the difficulties and errors in translating TV programs in English into Vietnamese and the possible solutions. The project involves a multidisciplinary study of audiovisual translation; in particular, voice-over translation that was undertaken with a mixed methodology including a descriptive model of content analysis and structured interviews. The framework linked Husar, Schwarz and Stiegelbauer's (2016) proposition of translation difficulties and Newmark (1991) and Malmkjor's (2004) error classification as a causal relationship. The translation difficulties were associated with the sources that caused translation errors. The proposition with three ramifications of linguistic, cultural and rendition categories was a grid to spot and parse these errors. The results revealed the most prominent translation errors that the translation trainees committed while doing the tasks of translation were linguistic errors (66.2\%), followed by rendition errors (20.6\%), and cultural errors (13.2\%), respectively. The difficulties as well as the sources of these errors found in this study included absence of English equivalents, a lack of linguistic proficiency, and inadequacy of cultural knowledge from SL and TL. The findings might be a parameter of skill-training for the futuristic voice-over translation for TV programs.
\end{abstract}

Keywords: Audio-Visual Translation; Corpus; Translation Difficulties; Translation Errors; TV Programs; Voice-Over Translation

Abbreviations: AI: Artificial Intelligent; AVT: Audiovisual Translation; LTV: Lam Dong Television Station; PACTE: Processes for Acquisition of Translation and Evaluation Competence; PT: Professional Translator; RQ: Research Question; SL: Source Language; ST: Source Text; TL: Target Text; TR: Translation Trainee

\section{INTRODUCTION}

Over the last three decades, Vietnam has been integrated into various international organizations and communities, first in the Asian region and then in the world. In this process of integration, the use of foreign languages has become significant. Among them, English has become the language to fill the gap between cultures, developed a market-oriented economy, contributed to diplomatic relations and improved national security. More and more multinational residents speak English. It is important that the Vietnamese people learn English so they also can communicate with this growing number of international citizens.

Working in the translation profession has never as simple as it is thought. An exact translation is nearly impossible, and much change in meaning often happens. If the translators mistranslate the idea or documents, it may cause a diplomatic scandal between two countries. The legal or technical documents which are incorrectly translated can deliver wrong messages and lead to illegal decisions. Indeed, there is a growing need of English translation and interpreting service providers in the Vietnamese society up to the present. A professional translator (PT henceforth) who has a good linguistic competence and cultural intelligence when doing their job are even more needed.

The Radio and Television Station of Lam Dong province (LTV henceforth) is one of the sixty-seven radio and television institutes at central and local levels in Vietnam. In 1997, a satellite Englishspeaking translated program was established in order to meet the cognitive demand of on-the-air information and entertainment. In the last twenty-years, language translation on LTV has played a vital behind-the-scene role in the development of Lam Dong Media Service. Among a total of thirty five television programs, there are fourteen translated programs broadcasted by LTV. These 
translations have provided information from around the world. Different from the other kinds of translation, voice-over translation is an audiovisual translation technique that is applied by the translation staff of LTV. Although voice-over translation can apply the general methods, strategies and techniques of translation theory, it has its own features.

Recently, LTV has had competition for advertising from cable TV, Internet, outdoor ads, print pieces, and other media categories. In addition, knowledge among radio listeners and TV spectators has significantly improved. LTV newsroom has to compete with multiplatform media for captivating more advertisers who desire to reach those audiences. With regard to building an audience base, the editors and reporters have to improve their program quality content and performance styles. To retain present followers and to appeal to more new watchers, there should be many program choices that are both interesting and informative. The source of these shows has expanded from a few local channels and now included programs from all over the world. Translators must be aware of the changing linguistic environment to ensure a 'shipshape' translation and maintain journalistic integrity.

Each year, senior students of the Foreign Language faculty at Dalat University are offered an internship to translate in the Program Department. In order to save time for the translation learners who have just had to both studies in the classroom and practice at LTV office. As the staff assigned as their facilitator, six professional translators at LTV have taken the form of hybrid e-learning for several months of internship over the last five years. That means PTs meet these trainees once a week to administer the clip for trainees to listen to, and then they email translated texts to their translatorsupervisor. These supervisors also comment on their translation through emails. If a translation trainee (TR henceforth) needs any help, the translators are willing to answer their questions over the phone or other mobile apps. However, there are empirical experiences such as rendering videos and voice-over presenting that requires them to be present for observation.

During four semesters at college, the students have been learning Translation course. The course plan is divided into four sections from Translation I to Translation IV. In the third semester, these students are trained with Translation Theory including translation definition, basic translation methods and strategies. In the following semesters, they are taught how to translate texts grouped by topics. The course books (for internal use only) were devised by teachers who were not work in the profession of translation. Therefore, their point of view of this occupation is not so realistic. Partially, the students do not have much time to expose this course. They surprisingly do not master all skills to make it professional.

As a result, most of these students have encountered hardships with this kind of work because it is very different from what they studied at school. Many more complaints have come from the translator-supervisors when the way stages are working within internships. Some blunders sometimes make TV audiences think the programs are translated by translation software. Several translated programs use far too many words and complicated vocabulary that the typical audiences do not understand. Modern TV onlookers seek relaxation and information in TV shows or movies, but inappropriate translations may annoy them.

The high demand of translations and the requirement of TV show quality force the translators to consistently strive. These changes and improvement are goals of the Program Department. Moreover, there is no doubt that the translation staff has faced challenges during their work because of linguistic and cultural barriers. The most obvious linguistic crisis is the constant alternation of vocabulary. In some cases, the words that were used in five years ago have different meanings in today's English; also, new words due to innovative products being introduced. Cultural updating may happen even faster than language. Translators, therefore, should be fully aware of the linguistic and cultural difficulties that they have to face so that they could equate translation quality.

Every year, different and new programs are being launched and need translating. The translatorsupervisors view that they must be proactive and helping TRs to move forward. Promoting translation skills must start early in the educational process at Dalat University. The translation-majored students should undergo efficient drilling in the early phase of their chosen career. It seems to be late if the imminent graduates wait until they take part in the translation program internship at LTV. A new curriculum must be designed to train the students to be able to recognize the linguistic and cultural changes. The new courses ought to reflect the findings of the research. 
In brief, translation is a hard work to do and voice-over translation is even more challenging. Not just inexperienced students, but PTs also face difficulties while doing their job. The difficulties seem to be a mismatch between voice-over content and images of source videos that lead to an anguished-filled TV programs. If the problems were not solved, the audience would turn away. It is important for the problems to be fixed because the translators' competence determines the quality of translation products. The study is in an attempt to intensively figure out the linguistic and cultural challenges in translating that both amateur TRs and master translators encounter. The study was inspired by a need of deep learning to the voice-over translation techniques that can be used to solve those drawbacks. The voice-over translation is likely to make the study distinctive to the previous research in the same field and contribute a new point-view that has untouched.

The study focuses on the following research question as follows:

- What are the difficulties that the translators and translation trainees at Lam Dong Radio and Television station encounter in translating TV programs in English into Vietnamese?

- What errors do the translation trainees make in translating TV programs in English into Vietnamese?

\section{OBJECTIVES OF THE STUDY}

The aforementioned problems have forced the translators at LTV to execute more research to unearth what caused the complaints and enhance TV programs. In addition to the goal of examining translation difficulties and errors that PTs and TRs encountered when translating from English into Vietnamese, boosting the staff's proficiency would be a preference. Some suggestions have been introduced to remedy the strategies for newcomer members of the staff in their work on TV programs including news, documentary films, movies and cartoons. This study aims to help devise skill-sets for translation students at Dalat University in order to be well-prepared for the internship at LTV and to bring to fruition in their future career. This aim is the focal point of this research.

\section{Material AND Methods}

\subsection{Research Design}

For the research design, a mixed research method is required. A descriptive model of translation review incorporates with qualitative methods. The latter was employed to gather information about the perception of translation errors which come from difficulties and construe the data of errors. Husar, Schwarz and Stiegelbauer (2016) propose that translation difficulties with two linguistic and cultural aspects and Newmark (1991) \& Malmkjor (2004) with linguistic errors, cultural errors and rendition errors are the main framework to assess which types of difficulties that the translators at LTV have met. The format of interview questions was adapted from PACTE Group's (2003) model and Khalifa's (2015) study. However, the interview questions were adjusted to comply with the context of LTV (Appendix A).

\subsection{Sample and Sampling Procedures}

The sample of the research consists of two groups. As a part of the sampling procedure, twenty-seven TRs $(n=27)$ of age twenty-two to twenty-three are impending graduates from Dalat University. Each translator supervisor was taking responsibility for four or five trainees during three months. The reason for picking up these students as part of the study was that they participated in translation internship programs at LTV at this moment. They might be candidates to become new trained workers who were seeking a translation job.

The second group is the LTV translation crews consisting of six PTs $\left(n^{\prime}=6\right)$ who have a bachelor's degree in the English language. Amongst the six translators, there are five females and one male in the twenty-six to forty-five age ranges. All of them graduated from Foreign Language Faculty of Dalat University. That is the reason why these former students have been willing to support graduates from their old school. Each PT is specialized in more than one particular field of TV program translation. The least experienced has translated for three years while the veteran has more than twenty-year experience. They are ideal subjects because they have experience in translating. They may give unique points of view to empirical problems and suggestions about the application of translation strategies. 
In this section, about eighty English-speaking audiovisual clips were chosen to administer to twentyseven TRs to listen to and transcribe to check their listening comprehension. Afterwards, they were asked to translate these videos into Vietnamese. Based on the translations done by PTs, the students' translations were checked for linguistic, cultural and rendition errors in the written texts. Each video clip which is part of a TV program is between four and forty minutes long. These clips are relevant to various fields. Translated written texts encompass from roughly 600 to 8,000 words. The review of the translated texts shows the students' linguistic proficiency, cultural knowledge and awareness of rendition errors. To avoid erroneous excess in several certain fields, a wide variety of video clips from various aspects were equally chosen. The team-work and individual work were also considered because TRs' errors in the same translation task can vary.

\subsection{Research Instruments}

At this stage, the research instruments include (1) document review and (2) structured interviews with the translators with nine open-ended questions.

\subsection{Data Collection Procedures}

At this moment, the translated written texts from the trainees and professional texts of the same videos from the translation staff at LTV were collected for the purpose of reviewing. According to many translation studies built on the dichotomy design, apart from content analysis, the interviewer approached each translator face-to-face at different times and in separate places. Each interview lasted about 30 minutes. All interviews were note-taken and then transcribed verbatim. To assure credibility and plausibility, the interviewer asked the respondents to review and approve the interview transcriptions and translations.

\subsection{Data Analysis Procedures}

After eighty translation texts were collected, the errors in TRs' translation were spotted and labelled. In particular, 'L1' stands for lexical errors and 'L2' for syntactic errors; ' $\mathrm{C} 1$ ' for inappropriate translation by SL cultural background inadequacy and ' $\mathrm{C} 2$ ' for thereof by TL cultural background inadequacy; ' $\mathrm{R} 1$ ' for too lengthy and/or redundant rendering and ' $\mathrm{R} 2$ ' for substance errors. A corpusbased approach was employed to calculate the categories of translation errors. AntConc software (version 3.5.0) with a numeric statistic function checks frequency and percentage of the occurring errors. Accordingly, the assessment of the source of these errors which mean difficulties was analyzed.

After the interviews with PTs were conducted, the translators' quotes were presented in systematic clusters that could be in the discussion section. The qualitative data may coincide with the analytical technique of systematic "enumeration" as Lecompte and Preissle (1993) indicate (cited in Cohen et al., 2007). In accordance with data interpretation, an inductive approach which provides a convenient way of dissecting qualitative data was employed to summarize the use of translation techniques to meet the voice-over mode of translation. Simultaneously, a deductive logic can be used to analyse quantitative data onto the questions which constitutes a mixed method to draw on the strengths of the combination (Ali and Birley, 1999). The next step was to discuss possible interview responses covering PT's opinions of translation difficulties, translation errors and suggestions of error remedies.

\section{RESULTS AND DISCUSSION}

\subsection{Content Analysis}

In this section, the result of reviewing eighty texts with roughly 104,960 word tokens translated by TRs was orderly elaborated under each rubric. The numeric data from the AntConc software was analyzed to discover how error frequencies happened. The source of these errors was explained in accord with the translation difficulties.

The overall performance of TRs on the translation tasks was average. As seen from Table 4.1, the results showed that the most frequent translation errors were linguistic errors $(66.2 \% ; 2220$ out of 3,354 major errors), followed by rendition errors (20.6\%; 692 out of 3,354 major errors), and cultural errors (13.2\%, 442 out of 3,354 major errors), respectively. As for linguistic errors, L1 (lexical errors) had the highest percentage, accounting for $48.1 \%$ of the total. The next was L2 (syntactic errors) with 607 out of 3,354 occurrences. In the second position, the most existence of rendition errors was R2 
Difficulties in Translating TV Programs in English into Vietnamese: A Study at Lam Dong Radio Television Station

(substance errors) with 457 points (13.6\% out of the total). As for cultural errors, the percentage of C2 (Inappropriate translation) caused by TL cultural background inadequacy was seen to be the lowest at $5.7 \%$ (190 out of 3,354 major errors). This apparently indicates that TRs excessively made lexical errors.

Table4.1. Translation errors in the translations of the trainees at LTV

\begin{tabular}{|l|l|l|l|}
\hline Label & \multicolumn{1}{|c|}{ Translation Errors } & Frequency & \% of total major errors \\
\hline L1 & Lexical errors & 1,613 & 48.1 \\
\hline L2 & Syntactic errors & 607 & 18.1 \\
\hline C1 & $\begin{array}{l}\text { Inappropriate translation by SL cultural background } \\
\text { inadequacy }\end{array}$ & 252 & 7.5 \\
\hline C2 & $\begin{array}{l}\text { Inappropriate translation by TL cultural background } \\
\text { inadequacy }\end{array}$ & 190 & 5.7 \\
\hline R1 & Too lengthy expression and/or redundant rendering & 235 & 7.0 \\
\hline R2 & Substance errors & 457 & 13.6 \\
\hline & Total major errors & $\mathbf{3 , 3 4 5}$ & $\mathbf{1 0 0}$ \\
\hline
\end{tabular}

\subsection{PTs' responses to the Interviews}

In the interviews, six PTs shared their preferences regarding translation difficulties, their opinion towards the voice-over translation mode, the evaluation towards TRs' internship and translation suggestions to deal with translation errors that they and TRs engaged in as follows.

As regards the fields of translation which PTs are responsible for, PT1- the male team leader- who is forty-three years-old and experienced twenty-two years has been in charge of 'Animal World' and 'Green-lives' which feature the natural environment of animal species and agricultural methods, respectively. The rest members of the PT team are female. As the same experienced period as PT1, forty-five-year-old PT2 has been attached with cultural and tourism channels for her 'Cultural Journeys' TV products. Forty-one-year-old PT3 with fourteen years working at LTV is good at translating natural sciences in 'Sciences and Lives'. As a peer of PT3, PT4 translates the genres of entertainment shows like 'Motion Picture Magazine' and 'Foreign Entertainment'. With over ten years at LTV, thirty-three-year-old PT5 serves for the children audience with cartoons and educational programs; and the least experienced twenty-five year-old PT6 specializes in translating the titular adaptation of 'Living skills'. They all said that every fields required particular word-stock and techniques.

Their translation issues abounded during their work but the most salient problems were unable to find the lexical equivalents and convey cultural features from SL to TL. PT3 explained the reason of her untranslatability was "I do not understand English humors, irony, idiomatic or fixed expressions" whereas PT4 blamed her troubles on "I understand but cannot find equivalence in TL". "TRs may be lack of cultural knowledge from SL" was presumed by PT5 while PT6 admitted that she was lack of TL cultural background. As could be expected, PTs' difficulties stretched out from lacking lexical equivalents to culture-cross experience in both languages. The most unsatisfactory statement during the interviews was "words have more than one meaning that generates barriers while translating." PTs explained how to select the correct meaning of words to be suitable for the context was a big deal.

As for the internship attention, PTs' report of this year TRs' competence was in general worse than previous years. Some TR's translations were not definitely wrong, but could be considered unnatural and inappropriate to Vietnamese viewers. TRs infringed on more than one error upon one item. A single item could be occurred more than one error. The linguistic, cultural and rendition errors appeared in their TRs translation due to numerous sources. PTs judged that the most frequent error of TRs fell into lexical categories. The voice of PTs seemed to be well resonated in the findings of the content analysis above. PT1 explicitly stated that "TRs induced the most frequent error is wrong word choice. They do not know how to pick the right meaning of the terms". It was interesting to note that PT2 pointed out that "Some translated sentences were nonsense because TRs were in lack of vocabulary. It was doubted that they used Google Translate." PT3 complained "I could not use my TRs' translation. Their translation was of low quality". PT4 and PT6 lamented more or less the same point of view. PT5 further discussed "They might be good at grammar at school but voice-over translation tasks in reality were different. They need much more skills and techniques rather than 
knowledge they mastered in class". Occasionally, the translation errors were unavoidable, even to the most experienced PT; however, they were aware of judicious proof-reading before sending their translated outcomes to the editorial board and voice-over presenters.

Four out of six PTs (66.7\%) strongly agreed that the voice-over translation with specific requirements and techniques is different from the other translation modes; one of them agreed with it and one had a neutral answer (Figure 1). Indeed, they seemed to apply both general translation strategies and specific techniques to meet the voice-over translation's requirements.

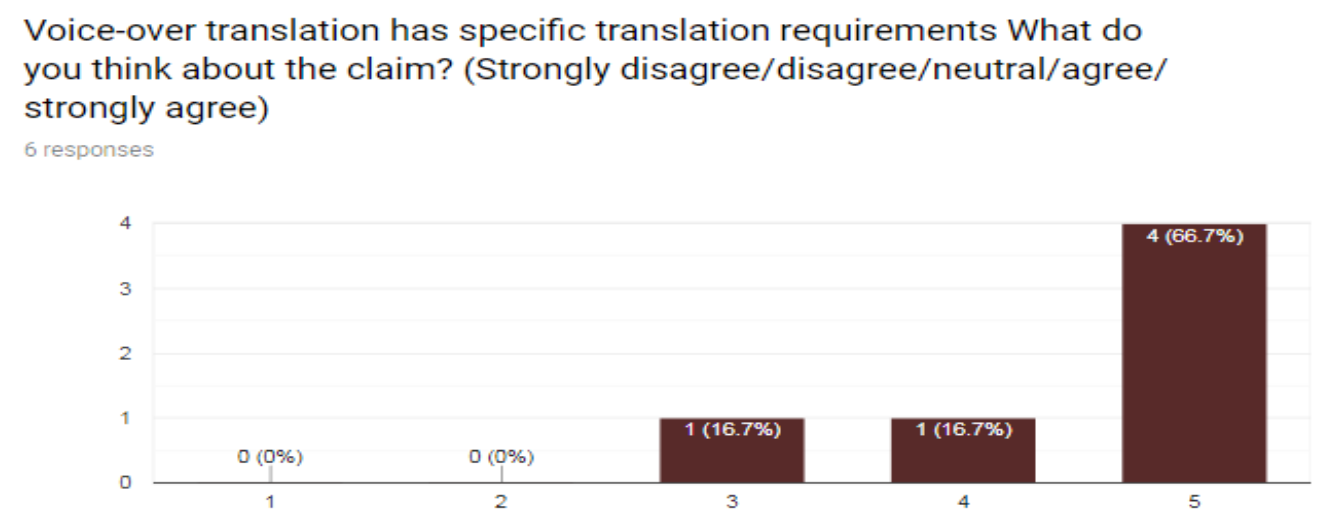

Figure1. Result of the interview question 5

As regards the specific techniques of voice-over translation, each interview's participant orderly proposed helpful solutions to revise TRs' errors on this below:

- PT1: Reduction (without making information loss or causing ambiguity)

- PT2 and PT3: Omission (without making information loss or causing ambiguity)

- PT4: "Meaning-driven" translation/ free translation

- PT5 and PT6: Paraphrasing and reconstruction

Most PTs also supported the technique of free translation to an incremental creativity in their work. The translators did not follow a rigid criterion of translation theories. Their method was to capture the main idea and then described on their words.

Given PTs' view on the suggestions to deal with translation difficulties and advice to TRs, an enumeration was elaborated as follows:

- PT1: "TRs should enrich their vocabulary, especially termilogical words by reading newspaper and practicing listening skills by watching movies with subtitles."

- PT2: "The Vietnamese sentence structures and grammars differ from those in English. We have to know how to express a message into Vietnamese style that sounds naturally."

- PT3: "To be good at one certain aspect, you have to be associated long with it. Actually, being experienced in translation is also beneficial in linguistic development; therefore, my advice is to keep your enthusiasm towards translation professions as much as possible and you would get a reward."

- PT4: "Cultural-cross differences make English-Vietnamese voice-over translation more demanding. Exposing cultural knowledge from ST and TL by reading book and watching various English-speaking programs is important to improve quality translations."

- PT5: "TRs should know how to effectively use reference materials, glossaries and dictionaries on the Internet. When they have more experience, they would less need these supportive tools and do their job efficiently."

- PT6: "TRs should not translate word for word that could limit their expression proficiency. Free translation without message loss or inaccuracy is allowed." 
Difficulties in Translating TV Programs in English into Vietnamese: A Study at Lam Dong Radio Television Station

\subsection{Discussion}

\subsubsection{Translation Errors Made by TRs and the Congruence of PTs' Voice During Interviews}

The results indicated that linguistic errors were detected the most. Lexical error was the most common linguistic error. The ratio of linguistic errors was over twice greater than the sum of rendition errors and cultural errors. This implies that TRs had more lexical difficulties than cultural issues. In the interviews, the participants' views of the most frequent translation errors conform to what were found in the content analysis section that was lexical errors. The most recurring lexical error was failure to recognize connotative meaning of words. This point was congruent to Komlev's (2012) types of translation errors. This might be understood that TRs found difficult to decide which meanings would be opted among variety of connotations.

Syntactic errors also made up a high rate in terms of linguistic errors. The conjunction words 'and' and 'but' that usually incepts English sentences led to a systematic error since TRs kept this SL syntactic structure and over generalized it into Vietnamese. The runner-up highest ratio of L2 (syntactic errors) showed up thanks to the word 'và' (and) and 'nhưng' (but) in the beginning of a sentence was explored. TRs extremely depended on the ST and did not put their efforts to the tasks. They did not realize that the exotic sentence structure was created. Finally, homophones and homonyms were seldom used in clips because of their complexity, even to the English native speakers; possibly, the less difficulties the less blunders were made.

The second place in the list of the translation errors was rendition errors (R). In fact, too lengthy and/or redundant rendering (R1) implied a semantic error that affects the meaning of the whole sentence while TRs and even PTs supposed R2 (substance errors) less important because R2 could not significant obscure the meaning. During the interviews, PTs did not mention to R2. They lively thought that typos were an unnoticed certainty. TRs attempted to complete the content, but neglected the form of texts. Probably, TRs did not take time to proofread; hence, the mistakes of spelling, typing, punctuation and capitalization had their place in these translations. Nonetheless, the voiceover translation requires a flowing and smooth typeface to ensure pleasant to read. They should follow step four "proofreading" and step five "final verification" in Biel's (2011) procedure of translating.

Cultural errors mainly occurred in the SL cultural touches; in other words, cultural practitioners usually come up with ideas, use their cultural horizon and manipulate rhetorical effectiveness during a creative and imaginative process. These acts them self take much time and effort; therefore, the cultural quizzes made up fewer than other genres that led to fewer difficulties and errors. Therefore, it would be no surprised when TRs committed C1 (Inappropriate translation by SL cultural background inadequacy) at a very low level. In the interviews, PTs pinpoints roots of cultural errors that were unawareness of inter and intra knowledge from both two cultures. On the other hand, another difficulty was worth noticing that TRs understood the social-cultural specific details but had no Vietnamese equivalents. These points matched Baker's (2011) concepts of non-equivalence.

\subsubsection{The Voice-over Translation and Theme-specialized Translation}

PTs were in agreement with the voice-over translation being a different form of AVT. This translation mode needs specific requirements and techniques such as reduction or omission without losing content or causing equivocation; free translation, paraphrasing and reconstructuring. Each example of translation main errors and sub-categories made by TRs was along the lines of possible revision and translation techniques of PTs found in Appendix B. PTs notified that every fields required particular word-stock and techniques. As would be anticipated, the lexical errors such as L1(1) (failure to translate jargons) in technical topics exceeded those in other themes. Cultural errors were outnumbered in tourism, film and art industry; especially, in dialogues of cartoons and movies.

\subsubsection{PTs' Recommendations}

Eventually, based on work experience and observation from internships at LTV, PTs put forward some suggestions. PTs recommended TRs to be aware of enhancing more new words, terminology, and cultural knowledge for a progressive translation. Manipulating Artificial Intelligent (AI) translation technology such as electronic dictionaries, online materials, and references was a priority of PTs' advice. Besides, cultivation of listening skills was one of the foci of voice-over translation to 
better understand the content in a given context of video clips. The database for practicing was from reading online newspapers, books, English-speaking TV programs and English subtitled movies. PT3 stated a long-term attachment with the translation job would be a reward for being a good translator. In reality, improving translation skills needs more factors than just time. A translator would not be progressive if he did not properly put his endeavour on the translation duty.

\section{CONCLUSION AND RECOMMENDATION}

\subsection{Conclusion}

In this study, the difficulties and errors of the professional translators and translation trainees at LTV were examined. PTs were associated with consent that voice-over translation is a different mode of translation. To answer two research questions (RQ) of the thesis, the review of TRs' documents and PT interviews were conducted.

As for RQ1, the answer for this question is relevant with a reply for the source of TRs translation errors. PTs and TRs had difficulties in both linguistic and cultural dimensions, but the rendition errors stemmed from carelessness. The difficulties as well as the causes of these errors found in this study included absence of English equivalents, a lack of linguistic proficiency, inadequacy of cultural knowledge from SL/TL and negligence. These factors were explored from the findings of content analysis and PT interviews. Based on the sample of PTs, the techniques were given to revise TRs' errors and solve difficulties. As a result, voice-over translation requires particular techniques such as reduction or omission without losing content or causing non-transparent, free translation, paraphrasing and reconstructuring. In the interviews, PTs' belief was more and less accord with the heuristics of linguistic scholars' theories presented in the previous studies. Their voice was also resonated in the findings of the content analysis above.

As for RQ2, the linguistic, cultural and rendition errors were all occurred in the process of doing translation tasks assigned to TRs. The results showed that the most frequent translation errors were linguistic errors (66.2\%), followed by rendition errors (20.6\%), and cultural errors (13.2\%), respectively. The most prominent rendition errors were R2 (substance errors) that surpassed the errors of R1 (too lengthy expression and/or redundant rendering) in the same category.

\subsection{The Implications of the Research}

The findings might be a parameter of skill-training for the futuristic voice-over translation for TV programs. This research might inspire Vietnamese translators and broadcasting commissioners to improve the quality of media translation to draw audience. Pedagogically, the research can reinvigorate college teachers for reasonable methods to orientate translation-majored students at Dalat University and other educational institutes towards a sufficient preparation for the job.

\subsection{The Limitations of the Research}

The findings reported in this study could not be generalized to other groups of translation-majored students of Dalat University because the study scope limited in the voice-over mode. In the content analysis, there is an overlap between multiple errors that could not set a clear boundary of those error categories. The internship duration (three months) was too brief; therefore, translation tasks administered to TRs were not enough to cover an exhaustive list of major and minor errors proposed by numerous scholars.

\subsection{Recommendations for Further Research}

As implications for further study, this research may offer opportunities for future research in more categories of translation errors and difficulties as well as methods to overcome these issues. The concepts could be longitudinally refined to construct a theoretical framework for applied linguistic study in the discipline of AVT rather than just in voice-over translation. Assigning each TR to translate all ranges of TV programs (rather than to do the translation tasks of his/her PT supervisor) would provide in-depth information about the error sphere. Also, the errors categories might be examined from a single sort of video clips in specific topic so that studies in more specific areas of TV programs would be carried out. 
Difficulties in Translating TV Programs in English into Vietnamese: A Study at Lam Dong Radio Television Station

\section{ACKNOWLEDGEMENT}

I would like to specially thank my supervisor Dr. Nguyen Thi Kieu Thu for her instructions and comments that were a great help to me in finishing this article and its relevant thesis. Her insight was valuable and encouraging.

I am deeply indebted to my enthusiastic colleagues at Lam Dong Radio- Television Station who have supported in my study efforts.

I would also like to express my gratitude to my family and my friends for their mental and financial support. Words may not demonstrate my love for them.

Last but not least, I would like to thank the translation trainees who inspired me ideas how to improve the translation training programs.

\section{REFERENCES}

[1] Ali, H. \& Birley Birley, S. (1999). Integrating deductive and inductive approaches in a study of new ventures and customer perceived risk. Qualitative Market Research: An International Journal 2(2), 103110. Retrieved from https://doi.org/10.1108/13522759910270016.

[2] Baker, M. (2011). In Other Words: A Course Book on Translation. London and New York: Routledge.

[3] Cohen, L., Manion, L., \& Morrison, K. (2007). Research methods in education (6 ${ }^{\text {th }}$ Ed.). London: Routledge.

[4] Husar, D. B., Schwarz, N. \& Stiegelbauer, L. R. (2016). Translation problems and difficulties in applied translation processes. Researchgate 12(3), 51-57.

[5] Khalifa, E. M. (2015). Problems in Translating English and Arabic Language' structure: A Case Study of EFL Saudi Students in Shaqra University. European Journal of Enlish Language and Literature Studies 3 (4), 22-34.

[6] Komlev, N. G. (2012). Components of the Content Structure of the Word. Paris: Mouton.

[7] Lam Dong Radio- Television Station (2016). Quá trình hình thành \& phát triển [The process of establishment and development]. Retrieved from http://lamdongtv.vn/tin-tuc-c85/qua-trinh-hinh-thanhphat-trien.html.

[8] Newmark, P. (1988). A Textbook of Translation. New York: Prentice Hall.

[9] Newmark, P. (1991). About Translation. Clevedon/ Buffalo/ Toronto/ Sydney: Multilingual Matters.

\section{APPENDIX A}

\section{Questions for Interviewing the Translators}

1. Anh/ chị đã làm công việc biên tập-biên dịch viên ở đài Lâm Đồng được bao nhiêu năm? How many years have you worked as an editor-translator at LTV?

2. Anh/ Chị phụ trách chương trình truyền hình nào?

Which TV programs are you responsible for?

3. Các chương trình của anh chị chuyên về lĩnh vực nào?

Which particular fields do your programs specialize in?

4. Trong công tác dịch thuật, anh/chị gặp từng gặp thử thách gì khó khăn nhất?

What were the most difficulties in the translation work that you have encountered?

5. Dịch thuyết minh có những yêu cầu dịch thuật riêng. Anh/ chị nghĩ sao về nhận định này? (Rất không đồng ý/ không đồng ý/ không có ý kiến/đồng ý/ rất đồng ý)

Voice-over translation has specific translation requirements. What do you think about the claim? (Strongly disagree/disagree/neutral/agree/strongly agree)

6. Những lỗi trong dịch thuyết minh mà người thực tập do anh chị phụ trách thường gặp nhất là gì? (Lỗi về ngôn ngữ, lỗi về văn hóa hay lỗi trình bày)

What is the most frequent/ serious errors in voice-over translation committed by TRs you instruct? Are they linguistic, cultural or redition? 
Difficulties in Translating TV Programs in English into Vietnamese: A Study at Lam Dong Radio Television Station

7. What are the reasons for these errors? Nguyên nhân của các lỗi này là gì?

8. Những kỹ thuật dịch chuyên biệt nào của thể loại dịch thuyết minh mà anh chị cảm thấy hữu ích đối với mình và người thực tập để giải quyết những khó khăn trong dịch thuật?

What specific techniques of voice-over translation do you think that is helpful for you and TRs to overcome the translation difficulties?

9. Bằng kinh nghiệm công tác của mình, anh/chị có đề xuất hoặc lời khuyên chung nào để nâng cao năng lực của người thực tập chuyên ngành dịch thuật tiếng Anh?

From your work experience, what recommendations or suggestions can you offer to improve the competence of the English translation trainees?

\section{APPENDIX B}

The PTs' suggestions to revise the TRs' translation errors

\begin{tabular}{|c|c|c|c|}
\hline Errors & Source text & $\begin{array}{l}\text { Professional Translator's } \\
\text { sample }\end{array}$ & $\begin{array}{l}\text { Translation } \\
\text { techniques }\end{array}$ \\
\hline \multicolumn{4}{|l|}{ 1. Linguistic errors } \\
\hline \multicolumn{4}{|l|}{ L1: Lexical errors } \\
\hline \multirow[t]{3}{*}{$\begin{array}{l}\text { L1(1): Failure to } \\
\text { translate jargons }\end{array}$} & (1) $\underline{s c i-f i \text { epics }}$ & $\begin{array}{l}\text { Phim sử thi khoa hoc viến } \\
\text { tương (PT5) }\end{array}$ & Explicitation \\
\hline & (2) Rotating Set & Phim truòng xoay (PT5) & Explicitation \\
\hline & (3) nine minute long take & $\begin{array}{l}\text { phân cảnh dài chín phút } \\
\text { (PT5) }\end{array}$ & $\begin{array}{l}\text { Explicitation and } \\
\text { transposition }\end{array}$ \\
\hline \multirow[t]{3}{*}{$\begin{array}{l}\text { L1 }(2): \text { Failure to } \\
\text { recognize connotative } \\
\text { meaning }\end{array}$} & $\begin{array}{l}\text { (4) Back to 1951, with Royal } \\
\text { Wedding which premiered } \\
\text { anti-gravity in a grand } \\
\text { fashion. }\end{array}$ & $\begin{array}{l}\text { Trở về năm 1951, phim "Đám } \\
\text { cưới hoàng gia" có cảnh phản } \\
\text { trọng lực trở thành môt trào } \\
\text { lưu thịnh hành.(PT2) }\end{array}$ & Explicitation \\
\hline & $\begin{array}{l}\text { (5) ... a giant walking stick } \\
\text { he leans on and poses with. }\end{array}$ & $\begin{array}{l}\text {... một cây gậy lớn để anh ta } \\
\text { vịn vào và tạo dáng.(PT1) }\end{array}$ & Explicitation \\
\hline & $\begin{array}{l}\text { (6) Wrap your scarf around } \\
\text { the front of your neck to your } \\
\text { back, keeping the ends even. }\end{array}$ & $\begin{array}{l}\text { Quấn khăn quanh tì trước ra } \\
\text { sau cồ, giữ cho hai đầu khăn } \\
\text { bằng nhau.(PT3) }\end{array}$ & Equivalence \\
\hline \multirow[t]{2}{*}{$\begin{array}{l}\text { L1(3): Unnecessary } \\
\text { repetition }\end{array}$} & $\begin{array}{l}\text { (7) These are } 13 \text { plants will } \\
\text { flourish easily in a backyard } \\
\text { garden or in containers just } \\
\text { add sun and water. Here is a } \\
\text { list of the top } 13 \text { easiest } \\
\text { vegetables you can grow. }\end{array}$ & $\begin{array}{l}\text { Đây là } 13 \text { loại rau cu dễ trồng } \\
\text { nhất trong chậu hoặc trong } \\
\text { sân sau nhà bạn mà chỉ cần có } \\
\text { nước và ánh nắng mặt trời. } \\
\text { (PT1) }\end{array}$ & $\begin{array}{l}\text { Reduction } \\
\text { (without making } \\
\text { information loss } \\
\text { or causing } \\
\text { ambiguity) and } \\
\text { reconstruction. }\end{array}$ \\
\hline & $\begin{array}{l}\text { (8) It's a place few people } \\
\text { have seen with their own } \\
\text { eyes. }\end{array}$ & $\begin{array}{l}\text { Đây là nơi mà ít người được } \\
\text { tận mắt chúng kiến. }\end{array}$ & $\begin{array}{l}\text { Reduction } \\
\text { (without making } \\
\text { information loss } \\
\text { or causing } \\
\text { ambiguity) } \\
\end{array}$ \\
\hline $\begin{array}{l}\text { L1(4): Ambiguous } \\
\text { translation }\end{array}$ & $\begin{array}{l}\text { (9)... as the samurai his } \\
\text { family killed. }\end{array}$ & $\begin{array}{l}\text {... là võ sĩ samurai người mà } \\
\text { gia đình anh ta đã giết chết. } \\
\text { (PT4) }\end{array}$ & $\begin{array}{l}\text { Faithful } \\
\text { translation }\end{array}$ \\
\hline \multirow[t]{2}{*}{$\begin{array}{l}\text { L1(5): Incorrect and } \\
\text { ambiguous reference } \\
\text { of pronouns }\end{array}$} & $\begin{array}{l}\text { (10) When John Landis } \\
\text { called Rick Baker to do the } \\
\text { makeup for An American } \\
\text { Werewolf in London, he } \\
\text { actually pulled him off an } \\
\text { incredibly similar project } \\
\text { called The Howling. }\end{array}$ & $\begin{array}{l}\text { Khi John Landis gọi cho Rich } \\
\text { Baker về việc hóa trang cho } \\
\text { phim "Người Sói ở London", } \\
\text { Landis thực sự đã cản trở } \\
\text { Baker tham gia vào một dự án } \\
\text { tương tự có tên "Ma Sói". } \\
\text { (PT5) }\end{array}$ & Explicitation \\
\hline & $\begin{array}{l}\text { (11) A prop that's association } \\
\text { with the character allows us } \\
\text { to think and talk and feel } \\
\text { about them even when } \\
\text { they're not on screen. }\end{array}$ & $\begin{array}{l}\text { Một món đạo cụ đi cùng với } \\
\text { nhân vật cho phép chúng ta } \\
\text { nghĩ, nói và cảm nhận về } \\
\text { chúng, dù cho chúng không } \\
\text { xuất hiện trên phim. (PT5) }\end{array}$ & Explicitation \\
\hline Contrary & (12) For this list we're & Danh sách này bao gồm các & Faithful \\
\hline
\end{tabular}


Difficulties in Translating TV Programs in English into Vietnamese: A Study at Lam Dong Radio Television Station

\begin{tabular}{|c|c|c|c|}
\hline translation & $\begin{array}{l}\text { looking at those airborne } \\
\text { vehicles from film that we } \\
\text { find most fascinating } \\
\text { however we're excluding } \\
\text { spaceships. }\end{array}$ & $\begin{array}{l}\text { phương tiện trên không trong } \\
\text { các bộ phim thú vị nhất, } \\
\text { ngoai trù những con tàu vũ } \\
\text { trụ. (PT5) }\end{array}$ & translation \\
\hline \multirow[t]{2}{*}{$\begin{array}{l}\text { L1(7): Mistranslation } \\
\text { by mishearing and } \\
\text { misunderstanding }\end{array}$} & $\begin{array}{l}\text { (13) We want to honor } \\
\text { things, items, objects, stuff... }\end{array}$ & $\begin{array}{l}\text { Chúng tôi muốn đề cập đến } \\
\text { những món đạo cụ và đồ } \\
\text { vật... }\end{array}$ & $\begin{array}{l}\text { Faithful } \\
\text { translation }\end{array}$ \\
\hline & $\begin{array}{l}\text { (14) If you're on a first- } \\
\text { name basis with all the } \underline{U P S} \\
\text { guys or can name every pitch } \\
\text { person on the Shopping } \\
\text { Network... }\end{array}$ & $\begin{array}{l}\text { Nếu tên bạn đứng đầu trong } \\
\text { danh sách của những anh } \\
\text { chàng làm nhiếm vu chuyến } \\
\text { phát nhanh hoạc thậm chí có } \\
\text { thể đặt tên cho từng người } \\
\text { trên Mạng Mua Sắm thì có lẽ } \\
\text { bạn đang mắc phải các vấn đề } \\
\text { về chi tiêu. (PT3) }\end{array}$ & $\begin{array}{l}\text { Faithful } \\
\text { translation }\end{array}$ \\
\hline \multirow[t]{2}{*}{ L1(8):Untranslatability } & $\begin{array}{l}(15) \quad \ldots \text { the panoramic } \\
\text { photograph technique, called } \\
\text { Slit scan, to shoot the } \\
\text { sequence in-camera. }\end{array}$ & $\begin{array}{l}\text {... kỹ thuật quay phim toàn } \\
\text { cảnh được gọi là Quét khe, để } \\
\text { ghi lại các cảnh trong camera. } \\
\text { (PT4) }\end{array}$ & Equivalence \\
\hline & $\begin{array}{l}\text { (16) It's a fun World War II } \\
\text { movie that combines } \frac{\text { banter, }}{\text { virtual }} \\
\text { with excellent } \\
\text { cinematography. }\end{array}$ & $\begin{array}{l}\text { Đây là một bộ phim thú vị về } \\
\text { Thế chiến thứ II kết hợp lối } \\
\text { diễn hài huớc với nghệ thuật } \\
\text { quay hình ảo xuất sắc. }\end{array}$ & Explanation \\
\hline $\begin{array}{l}\text { L1(9): Homophones } \\
\text { and homonyms which } \\
\text { cause confusion and } \\
\text { untranslatability }\end{array}$ & 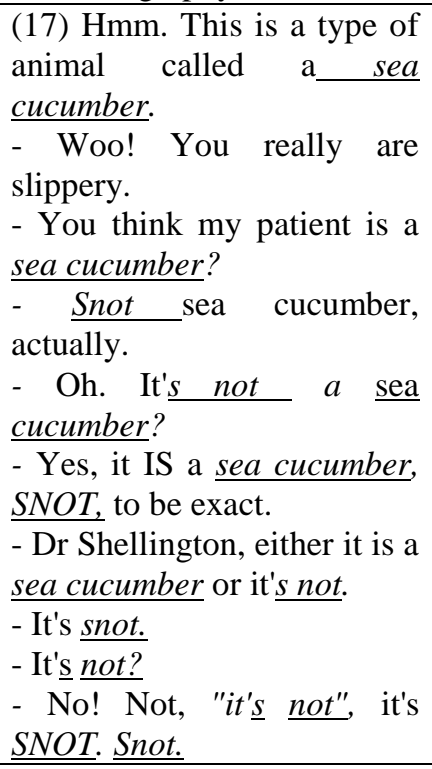 & 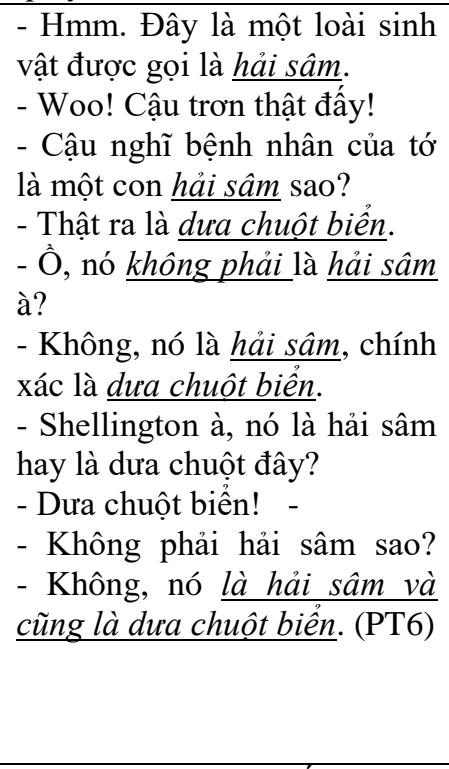 & Compensation \\
\hline \multirow[t]{3}{*}{$\begin{array}{l}\text { L1(10): Missing } \\
\text { important information }\end{array}$} & $\begin{array}{l}\text { (18) it's the epitome of the } \\
\text { cold-blooded killer. }\end{array}$ & $\begin{array}{l}\text { đó chính là vũ khí tối thượng } \\
\text { của kẻ săn mồi máu lạnh. } \\
\text { (PT1) }\end{array}$ & $\begin{array}{l}\text { Faithful } \\
\text { translation }\end{array}$ \\
\hline & (19) the laser samurai sword & $\begin{array}{l}\text { Thanh gươm la-de của } \underline{\text { vo } s \tilde{\imath}} \\
\text { Samurai (PT3) }\end{array}$ & $\begin{array}{l}\text { Naturalization } \\
\text { and addition }\end{array}$ \\
\hline & $\begin{array}{l}\text { (20) 1927's Wings won the } \\
\text { Academy Award, and it's } \\
\text { two on four Zeppelin run. }\end{array}$ & $\begin{array}{l}\text { Bộ phim“Đôi cánh" ra đời } \\
\text { năm } 1927 \text { đã giành giải của } \\
\text { Viện Hàn Lâm, và phim sủ } \\
\text { dung } 2 \text { trong số } 4 \text { tàu bay } \\
\text { Zeppelin còn hoat đông được. } \\
\text { (PT5) }\end{array}$ & Addition \\
\hline $\begin{array}{ll}\text { L1(11): } & \text { Nonsense } \\
\text { translation } & \end{array}$ & $\begin{array}{l}\text { (21) But the number one slot } \\
\text { goes to something which } \\
\text { was just incredibly clever } \\
\text { and, surprisingly, left on the } \\
\text { cutting room floor. }\end{array}$ & $\begin{array}{l}\text { Tuy nhiên, vị trí số một phải } \\
\text { thuộc về thứ gì đó thật thông } \\
\text { minh và bất ngờ. (PT2) }\end{array}$ & $\begin{array}{l}\text { Omission } \\
\text { (without making } \\
\text { information loss } \\
\text { or causing } \\
\text { ambiguity) }\end{array}$ \\
\hline $\begin{array}{lr}\text { L1(12): } & \text { Problems in } \\
\text { using } & \text { Vietnamese }\end{array}$ & $\begin{array}{l}\text { (22) Drink a lot of water - } \\
\text { ten eight-ounce glasses a }\end{array}$ & $\begin{array}{l}\text { Hãy uống nhiều nước, khoảng } \\
\text { mười cốc } 250 \mathrm{ml} \text { mỗi ngày. }\end{array}$ & $\begin{array}{l}\text { Faithful } \\
\text { translation }\end{array}$ \\
\hline
\end{tabular}


Difficulties in Translating TV Programs in English into Vietnamese: A Study at Lam Dong Radio Television Station

\begin{tabular}{|c|c|c|c|}
\hline \multirow{3}{*}{$\begin{array}{ll}\text { national } & \text { standard } \\
\text { language } & \end{array}$} & day... & (PT4) & \\
\hline & $\begin{array}{l}\text { (23) The most well-known is } \\
\text { the Tengger Caldera. }\end{array}$ & $\begin{array}{l}\text { Nồi tiếng nhất là miêng núi } \\
\text { lửa Tengger. (PT1) }\end{array}$ & $\begin{array}{l}\text { Faithful } \\
\text { translation }\end{array}$ \\
\hline & $\begin{array}{l}\text { (24) Wrap your scarf around } \\
\text { the front of your neck to } \\
\text { your back, keeping the ends } \\
\text { even. }\end{array}$ & $\begin{array}{l}\text { Vòng khăn tù đằng truớc ra } \\
\text { phía sau cồ, giữ cho hai đầu } \\
\text { khăn bằng nhau. (PT3) }\end{array}$ & Equivalence \\
\hline \multicolumn{4}{|l|}{ L2: Syntactic errors } \\
\hline $\begin{array}{l}\text { L2(1): Wrong order } \\
\text { of the sentence's } \\
\text { components }\end{array}$ & $\begin{array}{l}\text { (25) Indonesia is spread } \\
\text { across a chain of } 17,000 \\
\text { islands, between Asia and } \\
\text { Australia, known as an } \\
\text { archipelago. } \\
\end{array}$ & $\begin{array}{l}\text { Indonesia là một quần đảo } \\
\text { trải rộng với chuối } 17.000 \\
\text { hòn đảo, nằm giữa châu Á và } \\
\text { châu Úc. (PT1) }\end{array}$ & $\begin{array}{l}\text { Paraphrasing and } \\
\text { reconstruction }\end{array}$ \\
\hline \multirow[t]{2}{*}{$\begin{array}{l}\text { L2(2): Grammatical } \\
\text { errors of sentence } \\
\text { structures }\end{array}$} & $\begin{array}{l}\text { (26) And while that could be } \\
\text { 2010's Soar into the Sun, that } \\
\text { sees North and South Korean } \\
\text { air forces face off. }\end{array}$ & $\begin{array}{l}\text { Đó là bộ phim 'Biệt đội tiêm } \\
\text { kích' được phát hành năm } \\
\text { 2010, kề về cuộc đối đầu giữa } \\
\text { không quân Triều Tiên và } \\
\text { Hàn Quốc. (PT5) }\end{array}$ & $\begin{array}{l}\text { Grammatical } \\
\text { transposition }\end{array}$ \\
\hline & $\begin{array}{l}\text { (27) It took } 30 \text { technicians, six } \\
\text { months of preparation and a } \\
\text { whole week of shooting to } \\
\text { pull it off with ten hours each } \\
\text { morning for makeup } \\
\text { application, and three at night } \\
\text { for removal. }\end{array}$ & $\begin{array}{l}\text { Cảnh này cần đến } 30 \text { chuyên } \\
\text { gia và } 6 \text { tháng chuẩn bị cùng } \\
\text { nguyên một tuần ghi hình với } \\
10 \text { giờ mồi buối sáng hóa } \\
\text { trang và } 3 \text { giờ buổi tối để tẩy } \\
\text { trang.(PT5) }\end{array}$ & $\begin{array}{l}\text { Paraphrasing and } \\
\text { reconstruction }\end{array}$ \\
\hline \multicolumn{4}{|l|}{ 2. Cultural errors } \\
\hline \multicolumn{4}{|c|}{ C1: Inappropriate translation caused by SL cultural background inadequacy } \\
\hline \multirow[t]{2}{*}{$\begin{array}{l}\text { C1(1): Inability to } \\
\text { translate } \quad \text { cultural } \\
\text { terms }\end{array}$} & $\begin{array}{l}\text { (28) Well, I'll be a sea } \\
\text { monkey's uncle! This is kind } \\
\text { of fun. }\end{array}$ & $\begin{array}{l}\text { Chà, nếu vậy thì tôi sẽ 'đi đầu } \\
\text { xuống đất'! Thật là thú vị!' } \\
\text { (PT3) }\end{array}$ & Substitution \\
\hline & $\begin{array}{l}\text { (29) There have been } \\
\text { countless other Disney } \underline{\text { Easter }} \\
\text { eggs at MCU offerings }\end{array}$ & $\begin{array}{l}\text { Có vô số bất ngò thú ví của } \\
\text { Disney ẩn giấu trong các bộ } \\
\text { phim cúa Marvel. (PT5) }\end{array}$ & Substitution \\
\hline \multirow[t]{3}{*}{$\begin{array}{l}\mathrm{C} 1(2): \quad \text { Failure } \\
\text { translate idiolects }\end{array}$} & (30) Shiver me whiskers! & $\begin{array}{l}\text { Quả là đáng sợ!/ Tuyệt cú } \\
\text { mèo! (PT2) }\end{array}$ & Free translation \\
\hline & (31) Crumb! & Tiêu rồi! (PT2) & Free translation \\
\hline & (32) Carrot! & Tiêu rồi! (PT2) & Free translation \\
\hline $\begin{array}{lll}\mathrm{C} 1(3): & \text { Failure } & \text { to } \\
\text { translate dialects } & \\
\end{array}$ & $\begin{array}{l}\text { (33) That was some gnarly } \\
\text { surfing. }\end{array}$ & $\begin{array}{l}\text { Mấy cú lướt sóng đó cũng } \underline{r a} \\
\text { trò đấy chứ. (PT4) }\end{array}$ & Substitution \\
\hline $\begin{array}{l}\text { C1(4): Failure to } \\
\text { translate slang }\end{array}$ & $\begin{array}{l}\text { (34) Dashi, the amazing Octo- } \\
\text { dudette! }\end{array}$ & $\begin{array}{l}\text { Cậu là cô nàng Octo tuyệt vời } \\
\text { đấy, Dashi à! (PT4) }\end{array}$ & Substitution \\
\hline $\begin{array}{lr}\text { C1(5): } & \text { Failure to } \\
\text { translate } & \text { phrasal } \\
\text { verbs } & \end{array}$ & $\begin{array}{l}\text { (35) But he leaves the village } \\
\text { for Rome, insisting that } \\
\text { Andrei take up his candlelit } \\
\text { mantle. }\end{array}$ & $\begin{array}{l}\text { Ông ấy rời khỏi làng đến } \\
\text { Rome, khăng khăng rằng } \\
\text { Andrei sẽ kế tuc sứ mệnh thắp } \\
\text { nến của mình. (PT3) }\end{array}$ & Explicitation \\
\hline \multirow[t]{2}{*}{$\begin{array}{l}\text { C1(6): Inappropriate } \\
\text { translation of idioms }\end{array}$} & (36) Like father like son. & 'Cha nào con nấy.' (PT6) & $\begin{array}{l}\text { Cultural } \\
\text { equivalence }\end{array}$ \\
\hline & $\begin{array}{l}\text { (37) Throw a spat to catch a } \\
\text { herring. }\end{array}$ & $\begin{array}{l}\text { 'Thả con tép, bắt con tôm' } \\
\text { (PT6) }\end{array}$ & $\begin{array}{l}\text { Cultural } \\
\text { equivalence }\end{array}$ \\
\hline $\begin{array}{l}\text { C1(7): Inappropriate } \\
\text { translation of proverbs }\end{array}$ & $\begin{array}{l}\text { (37) The emotional stress was } \\
\text { harder than the physical } \\
\text { strain. }\end{array}$ & $\begin{array}{l}\text { Tâm bệnh đáng sợ hơn đau } \\
\text { đớn thể xác. (PT4) }\end{array}$ & $\begin{array}{l}\text { Cultural } \\
\text { equivalence }\end{array}$ \\
\hline \multirow{2}{*}{$\begin{array}{lr}\mathrm{C} 1(8): & \text { Under- } \\
\text { translation } & \text { and } \\
\text { inaccurate } & \\
\text { identification } & \text { of } \\
\text { proper name/ entity }\end{array}$} & $\begin{array}{l}\text { (38) So he called up } \underline{\text { Rick }} \\
\text { Baker to do it with make-up } \\
\text { instead. }\end{array}$ & 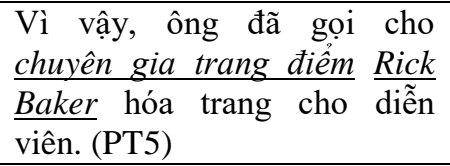 & Addition \\
\hline & $\begin{array}{l}\text { (39) this beloved film } \\
\text { adaptation of Diana Wynne } \\
\text { Jones novel ... }\end{array}$ & $\begin{array}{l}\text { Bộ phim được yêu thích này } \\
\text { chuyển thể từ tiểu thuyết của } \\
\text { tác giả Diana Wynne Jones... } \\
\text { (PT2) }\end{array}$ & Addition \\
\hline
\end{tabular}


Difficulties in Translating TV Programs in English into Vietnamese: A Study at Lam Dong Radio Television Station

\begin{tabular}{|c|c|c|c|}
\hline & $\begin{array}{l}\text { (40) From the brilliant mind } \\
\text { of Ian Fleming... }\end{array}$ & $\begin{array}{l}\text { tù trí tuê tuyệt vời của nhà } \\
\text { văn Ian Fleming... (PT2) }\end{array}$ & Addition \\
\hline & $\begin{array}{l}\text { (41) Is it an awesome way to } \\
\text { tell us that a T-Rex is coming. }\end{array}$ & $\begin{array}{l}\text { Đó là cách báo hiệu cho } \\
\text { chúng ta biết một con khủng } \\
\text { long ăn thịt/ T-rex đang đến. } \\
\text { (PT1) }\end{array}$ & Addition \\
\hline $\begin{array}{l}\text { C1(9): Inappropriate } \\
\text { translation of ironies }\end{array}$ & $\begin{array}{l}\text { (42) And if a clown falls over } \\
\text { in a forest and nobody laughs, } \\
\text { does he still get paid? }\end{array}$ & $\begin{array}{l}\text { Nếu một chú hề té ngã trong } \\
\text { rừng mà chẳng ai thấy để } \\
\text { cười cả, thì chú ấy vẫn đươc } \\
\text { trả công làm trò chứ? (PT3) }\end{array}$ & Explanation \\
\hline $\begin{array}{l}\text { C1(10): } \text { Confusing } \\
\text { proper names with } \\
\text { content words }\end{array}$ & $\begin{array}{l}\text { (43) 'Singing in the Rain's' } \\
\text { umbrella is a wonderful song } \\
\text { and dance version of this. }\end{array}$ & $\begin{array}{l}\text { Điệu nhảy dùng đạo cụ là } \\
\text { chiếc ô trong bộ phim "Khúc } \\
\text { hát dưới mưa" đã trở thành } \\
\text { một phiên bản ca vũ tuyệt } \\
\text { vời. (PT5) }\end{array}$ & $\begin{array}{l}\text { "Meaning- } \\
\text { driven" } \\
\text { translation/ free } \\
\text { translation }\end{array}$ \\
\hline \multicolumn{4}{|c|}{ C2: Inappropriate translation caused by TL cultural background inadequacy } \\
\hline \multirow{4}{*}{$\begin{array}{lr}\mathrm{C} 2(1): \text { Informality } \\
\text { and } \\
\text { overgeneralization of } \\
\text { personal pronouns/ } \\
\text { objectives r in } \\
\text { translating short } \\
\text { documentary videos }\end{array}$} & $\begin{array}{l}\text { (44) But where would we be if } \\
\text { we didn't mention the original } \\
\text { trilogy's practical effects? }\end{array}$ & $\begin{array}{l}\text {... nhưng sẽ là thiếu sót nếu } \\
\text { không đề cập đến hiệu ứng } \\
\text { thực tế của bộ ba phim gốc. } \\
\text { (PT5) }\end{array}$ & $\begin{array}{l}\text { Paraphrasing and } \\
\text { reconstruction }\end{array}$ \\
\hline & $\begin{array}{l}\text { (45) Check it out, there's no } \\
\text { computer here. }\end{array}$ & $\begin{array}{l}\text { Mời quý vị (và các bạn) hãy } \\
\text { kiểm chứng, không hề có sự } \\
\text { can thiệp/trợ giúp nào của } \\
\text { máy tính. (PT3) }\end{array}$ & Addition \\
\hline & (46) Right, just kidding it's & (Omitted) (PT1) & $\begin{array}{l}\text { Omission } \\
\text { (without making } \\
\text { information loss } \\
\text { or causing } \\
\text { ambiguity) }\end{array}$ \\
\hline & $\begin{array}{l}\text { (47) Every effect is hand- } \\
\text { modeled by (Rob) Bottin and } \\
\text { his team... }\end{array}$ & $\begin{array}{l}\text { Mọi hiệu ứng đều được } \\
\text { Bottin và ê-kíp của mình/ ông } \\
\underline{\hat{a} y)} \text { thực hiện thủ công. (PT5) }\end{array}$ & Transposition \\
\hline $\begin{array}{l}\mathrm{C} 2(2): \quad \text { Failure } \\
\text { translating titles }\end{array}$ & $\overline{(48)}$ 'Star War: A New Hope’ & $\begin{array}{l}\text { "Chiến tranh giữa các vì sao", } \\
\text { phần phim "Niềm hi vọng } \\
\text { mới" (PT5) }\end{array}$ & Explanation \\
\hline \multirow[t]{5}{*}{$\begin{array}{l}\text { C2(3): Unchanged } \\
\text { measurement units } \\
\text { and other specifically } \\
\text { social details from } \\
\text { SL to TL }\end{array}$} & $\begin{array}{l}\text { (49) ...to model that first Star } \\
\text { Destroyer at } \underline{50} \text { feet long }\end{array}$ & $\begin{array}{l}\text {... nhằm dựng mô hình con } \\
\text { tàu Star Destroyer đầu tiên } \\
\text { với độ dài khoảng } 15 \text { mét. } \\
\text { (PT3) }\end{array}$ & Localization \\
\hline & $\begin{array}{l}\text { (50) Monitoring your weight } \\
\text { is difficult when it can } \\
\text { fluctuate three to five pounds } \\
\text { in a single day. }\end{array}$ & $\begin{array}{l}\text { Theo dõi cân nặng quả là điều } \\
\text { khó khăn khi nó có thể dao } \\
\text { động tù̀ mồt đến hai kilogram } \\
\text { trong ngày. (PT3) }\end{array}$ & Localization \\
\hline & $\begin{array}{l}\text { (51) Drink a lot of water }-10 \\
\underline{\text { 8-ounce glasses a day }}\end{array}$ & $\begin{array}{l}\text { Hãy uống nhiều nước, khoảng } \\
10 \text { cốc } \underline{250 \quad m l} \text { mỗi ngày. } \\
(\mathrm{PT} 3)\end{array}$ & Localization \\
\hline & $\begin{array}{l}(52) \text { a child or adult's } \\
\text { temperature is over } \underline{103} \\
\underline{\text { degrees, }} \text {, see a doctor. }\end{array}$ & $\begin{array}{l}\text { Nếu nhiệt độ của một đứa trẻ } \\
\text { hoặc người lớn hơn } 39 \text { đô } C \\
\text { thì nên đi khám bác sĩ. } \\
\text { (PT3) }\end{array}$ & Localization \\
\hline & $\begin{array}{l}\text { (53) Call } \underline{911} \text { if your child } \\
\text { gets hurt badly. }\end{array}$ & $\begin{array}{l}\text { Hãy gọi } 115 / \text { xe cúu thuoong } \\
\text { nếu con bạn bị thương } \\
\text { nghiêm trọng. (PT3) }\end{array}$ & Localization \\
\hline \multicolumn{4}{|l|}{ Rendition Errors } \\
\hline \multicolumn{4}{|c|}{ R1: Too lengthy and/or redundant rendering } \\
\hline & $\begin{array}{l}\text { (54) If you're thinking } \\
\text { Inception, that's a good guess, } \\
\text { because the fight } \\
\text { choreography in the hallway } \\
\text { sequence is absolutely } \\
\text { astounding. }\end{array}$ & $\begin{array}{l}\text { Đó là phim "Kẻ cắp giấc mo" } \\
\text { với thiết kế võ thuật đáng } \\
\text { kinh ngạc trong phân cảnh } \\
\text { đánh nhau ở hành lang. } \\
\text { (PT5) }\end{array}$ & $\begin{array}{l}\text { Paraphrasing and } \\
\text { reconstruction }\end{array}$ \\
\hline
\end{tabular}


Difficulties in Translating TV Programs in English into Vietnamese: A Study at Lam Dong Radio Television Station

\begin{tabular}{|c|c|c|c|}
\hline & $\begin{array}{l}\text { (55) any soccer mom with } \\
\text { iMovie could probably create } \\
\text { a home video Stargate } \\
\text { montage }\end{array}$ & $\begin{array}{l}\text { bất kì ai cũng có thể tự tạo ra } \\
\text { một video không gian ào tại } \\
\text { nhà với ứng dụng Imovie. }\end{array}$ & Replacement \\
\hline \multicolumn{4}{|c|}{ R2: Substance errors } \\
\hline \multirow[t]{2}{*}{ R2(1): Spelling errors } & $\begin{array}{l}\text { (56) a spy plane capable of } \\
\text { upwards of } \underline{M a c h ~} 3\end{array}$ & $\begin{array}{l}\text { một máy bay do thám có thể } \\
\text { đạt tốc độ siêu thanh Mach } 3 .\end{array}$ & Addition \\
\hline & (57) saturation & độ $\underline{b a \tilde{o}}$ hòa & $\begin{array}{l}\text { Faithful } \\
\text { translation }\end{array}$ \\
\hline R2(3): Typos & $\begin{array}{l}\text { (58) that's actually a hole into } \\
\text { another identical but mirrored } \\
\text { room. }\end{array}$ & $\begin{array}{l}\text { Thật ra có một lỗ hổng bên } \\
\text { trong một lố hổng tương tự } \\
\text { được đặt trong một căn phòng } \\
\text { toàn gương. }\end{array}$ & $\begin{array}{l}\text { Faithful } \\
\text { translation }\end{array}$ \\
\hline \multirow[t]{3}{*}{$\begin{array}{l}\text { R2(4): } \quad \text { Punctuation } \\
\text { errors }\end{array}$} & $\begin{array}{l}\text { (59) The Howling didn't end } \\
\text { up nearly as successful as } \frac{A n}{\text { in }} \\
\text { American Werewolf } \\
\text { London. }\end{array}$ & $\begin{array}{l}\text { Phim "Nguời Sói hồi sinh" } \\
\text { đã không thành công vang dội } \\
\text { như phim "Ma Sói }{ }^{\circ} \\
\text { London". }\end{array}$ & Addition \\
\hline & $\begin{array}{l}\text { (60) And the result is } \\
\text { phenomenal. Not only is the } \\
\text { story a tale of a madman } \\
\text { trying to drag a river boat... }\end{array}$ & $\begin{array}{l}\text { Kết quả thật phi thường. } \\
\text { Không chì là câu chuyện kề } \\
\text { về một kẻ điên ra sức kéo con } \\
\text { thuyền... }\end{array}$ & Explicitation \\
\hline & $\begin{array}{l}\text { (61) He uses it for fighting, } \\
\text { mobility, escape, romance. } \\
\text { Along with his hat, it single } \\
\text { handedly invokes his image. }\end{array}$ & $\begin{array}{l}\text { Ông dùng nó để chiến đấu, di } \\
\text { chuyển, trốn thoát và bày tỏ } \\
\text { tình cảm. Cùng với chiếc nón, } \\
\text { nó đã góp phần tạo nên hình } \\
\text { ảnh cho ông. }\end{array}$ & $\begin{array}{l}\text { Faithful } \\
\text { translation }\end{array}$ \\
\hline
\end{tabular}

\section{AUTHORS' BIOGRAPHY}

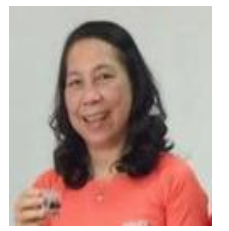

Dr. Nguyen Thi Kieu Thu is the Dean of the Faculty of English Language, Ho Chi Minh City University of Technology, Vietnam. Her research areas of interest are mainly EFL teaching methodology, translation, language learning strategies, and discourse analysis.

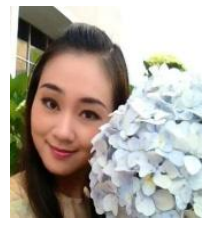

Ms. Nguyen Le Uyen Minh is currently an MA student in English language at Ho Chi Minh City University of Technology, Vietnam. She has been working as a translatoreditor at Radio and Television Station of Lam Dong province for more than nine years. Her research areas include language skills, discourse analysis, and EFL teaching methodology.

Citation: Nguyen Le Uyen Minh, Nguyen Thi Kieu Thu. "Difficulties in Translating TV Programs in English into Vietnamese: A Study at Lam Dong Radio - Television Station" International Journal on Studies in English Language and Literature (IJSELL), vol 7, no. 5, 2019, pp. 13-26. doi: http://dx.doi.org/10.20431/23473134.0705002.

Copyright: (C) 2019 Authors. This is an open-access article distributed under the terms of the Creative Commons Attribution License, which permits unrestricted use, distribution, and reproduction in any medium, provided the original author and source are credited. 